\title{
Self-Concept and Career Development of Santri Welcoming the Society 5.0
}

\author{
Minhaji ${ }^{1}$, Samsul Arifin ${ }^{2}$ \\ \{minhaji@ibrahimy.ac.id ${ }^{1}$, syamsulahasan@ibrahimy.ac.id²\} \\ Universitas Ibrahimy, Situbondo, Indonesia ${ }^{12}$
}

\begin{abstract}
The purpose of this study was to strengthening character education through development the ideal self-concept of female santri (students) from Pondok Pesantren Salafiyah Syafi'iyah Sukorejo in Situbondo Indonesia through into the society 5.0 era. Methods of expecting service-learning (SL); preferred from the review of the subjects "Personality Psychology", "Islamic Psychology", and "Islamic Guidance and Counseling" are then aligned with the needs of the santri community. Results: The development of the ideal santri self-concept is a generation of khaira ummah with the character of "Pelopor" (faith and civilization building). To implement the khaira ummah generation, santri develop a personal design of their personal qualities that balances shalahiyyah (the quality of skills) with shalih (integrity). Mastered: master and practice knowledge (alim); honest and enterprising (as-shidq); love and care (rahmah); able to control themselves (zuhud, sabar, and wara'); simple and modest (ikhlas, qonaah and ridha); tawadhu' and wawas diri (guard appearance, speech, and heart); and communicative. The self-concept of santri which is charged with worship and builds civilization; in accordance with the developmental self-concept theory.
\end{abstract}

Keywords: Self Concept, Career Development, Society 5.0

\section{Introduction}

The pondok pesantren (Islamic boarding schools) are preparing to enter a new civilization, era society 5.0. Society 5.0 is a new social order centered on human values that integrate cyberspace and physical space. The goal of society 5.0 is to realize a new, more humane order of life; economic growth and development of information technology for shared prosperity. The notion of community 5.0 originated in Japan, but the idea was relevant to be applied in all countries [1], [2]. We must connect the ideas of communitybased 5.0 to human values with self. If we want to understand humans, we must start from understanding ourselves. Self is a core aspect of personality [3], [4].

While personality is the most important and fundamental element in the study of psychology; because it reveals how individuals think and behave in everyday life. Self is a belief that we hold about ourselves; what are the important characteristics of ourselves? What are our potential and strengths? What are our weaknesses? Our self-understanding is also strongly influenced by our social context. Because self-understanding is not only internal but also a social-cognitive construction [3]. There are three forms of definition of self-identity, namely: first, individual self, namely self-defining based on personal trait that distinguishes from others. Second, rational self, which is defined based on interpersonal relationships that are owned by others. Third, collective self is self-defined based on 
membership in a social group [5], [6]. Every individual has all three forms of self. However, in cultures that uphold togetherness, such as the Indonesian context, people tend to express their identity in social categories and groups (collective self) rather than individual self [7], [8]

There are no studies on self-concept in the context of the santri community, for example Santri Salafiyah Syafi'iyah Sukorejo. One of the personality profiles of Santri Sukorejo expected (ideal self) by the founders of Pondok Pesantren Sukorejo is to have the ability to communicate with others (interpersonal intelligence). According to Kiai As'ad, Sukorejo cadres should have the ability to communicate with a mass base, a wide network, and be useful [9]. Therefore, the researcher tries to uncover the social identity of the Salafiyah Syafi'iyah Sukorejo santri. Most of the self-identities santri come from the social category they are in [10].

The focus of this research is strengthening character education through development the self-concept description of khaira ummah for female santri Pondok Pesantren Salafiyah Syaf'iyah Sukorejo in Situbondo and implementation in developing the self-concept to meet the era of society 5.0. The concept of self in this study leads to how the desired santri (ideal self) as desired by the founder of the pesantren namely Kiai Syamsul Arifin, Kiai As'ad Syamsul Arifin, and Kiai Fawaid As'ad, which will lead to social identity theory santri. Social identity theory assumes humans have a positive self-concept by identifying themselves through certain social groups [8]. Thus, social identity is part of an individual's self-concept.

\section{Research Method}

This study uses a service-learning research method through group counseling. Servicelearning is an approach method derived from the practice of applying the sciences of counseling and psychology learned in lectures to be practiced in the pesantren community [11], [12]. The study population was 60 students who attended the lectures "Islamic Guidance and Counseling", "Personality Theory", and "Islamic Psychology" with purposive sampling. While the stages of data analysis, namely: First, the part of the investigation is mapping all potentials and identifying the problems of the santri community. Second, the planning and preparation. Third, the action part, namely the provision of materials and the preparation of self-concept development designs with students and students. Fourth, the reflection section in the form of assignment sheets for students and students related to selfdevelopment. Fifth, the demonstration section of the results which is demonstrated in a lecturer discussion and publication of scientific papers.

\section{Results and Discussion}

\subsection{The ideal self-concept as a leader with khaira ummah character}

The self-concept is a person's perception of what is desired about him or beliefs about what should be about him [13], [14]. Ideal self-concept, including part of self-concept. The ideal concept contains the potential to bridge differences and manage expectations between pondok pesantren and santri administrators. Because in essence, ideal includes desire, imperfection, and reality [15]. The ideal self-concept of Sukorejo santri is as in Pondok 
Sukorejo's vision of giving birth to a generation of khaira ummah. Khaira ummah is a person who always invites goodness, prevents munkar, and believes in Allah (QS Ali Imron: 110). The vision of the khaira ummah with Ibrahimy University is elaborated with five superior values, namely as-shidqu (honesty, sincerity, and openness), al-amanah wal wafa bil 'ahd (trustworthy, loyal, and correct promises), al-'adalah (objective, proposial, and obedient principle), At-ta'awun (cooperation and help), and istiqomah (continuous and continuous) [16], [17].

Personal khaira ummah is a personal figure who carries the task as a servant of God (worship) as well as the khalifah of God (building civilization and making prosperity). Kiai As'ad formulated the khaira ummah in the term "Pelopor" meaning "fa (pemimpin)" means leader, "lam (lillah) " means because of Allah, "fa (pemimpin)" means leader, "ra (rakyat)" means people; namely a person who can be a leader in the path of Allah (da'wah) and a leader who fights for the people for prosperity and happiness in the afterlife [9], [18]. In building civilization and prosperity, Kiai As'ad emphasized the students to take an active role in education, preaching through NU, and thinking about the economy of the people. Whoever santri Sukorejo plays an active role in one of these fields, he will be perfect and happy in his life [18]-[20].

\subsection{Ideal self: aligning the quality of shalahiyyah with the integrity of shalih}

To implement the self-concept as the leader of the khaira ummah, the santri conduct a self-scheme. Self-schema iqws how a person thinks about his personal quality in a particular life domain [7], [8], [10]. Self-schemes not only describe how they are themselves but are also future-oriented about what they want to achieve, or what they fear will become. The self-schema includes self-understanding especially the ideal self or how the santri self is desired. The ideal quality of santri from Salafiyah Syafi'iyah self, among others:

\subsubsection{Alim (mastering and applying knowledge)}

Kiai As'ad gave a recipe for success about the quality of self that a santri must possess, that is alim. Alim is when a santri masters, practices knowledge (for himself and the community) and hopes for Allah's pleasure. The mastery of science is not just for life in the world but also to achieve safety and happiness in life in the world and the hereafter akhirat [16], [18], [21].

\subsubsection{Honest and enterprising (As-Shidqu)}

The character of as-shidqu means honesty, sincerity, and openness or known as honest and enterprising. According to Kiai As'ad, santri who are honest, enterprising, and sincere santri of Sukorejo will be safe and victorious. Kiai As'ad also reminded santri to be serious in optimizing themselves in learning. Santri must return to the pesantren khittah, namely the intention to seek knowledge and study hard [16], [19], [21].

\subsubsection{Affection (rahmah)}

According to Kiai As'ad, the quality of personality that must be possessed by teachers is compassion and hospitality. In the moral books that are taught in pondok pesantren always emphasize that teachers always love and love their students. According to Kiai Azaim, one indication of affection is a sincere charming smile. A smile is an expression of the inner joy of someone who can foster happiness and ultimate peace [17], [18], [21]. The attitude of the teacher's affection towards the santri will give birth to the santri respect (ta'zhim). If a teacher loves santri, santri will respect the teacher. So, there is an interpersonal relationship between 
teacher-santri. Even this interpersonal relationship is not just an outer relationship but also touches the inner self. For example, after each prayer or will learn the santri pray for the teacher. Likewise, the teacher prayed for the santri, to gain blessed knowledge. The bonds of love and respect, until the students stopped from the pesantren [21], [22].

\subsubsection{Able to control oneself: wara', zuhud, and sabar}

There are three characters related to our independence and ability to control ourselves; i.e. wara', zuhud, and sabar. Wara' is the attitude of caution by leaving something that is doubtful (syubhat) and not useful. Wara' is the stability of the heart, when he is passionate about doing an action so that he can distinguish between right and wrong. Wara' actually leaves something that is still doubtful in status and then chooses something that is unquestionably correct [21], [23]. Wara' is the beginning of zuhud. People who zuhud will not feel proud of the pleasures of the world and will never complain because of losing the world. Wara' and zuhud are among the stations or stages of the path that a Sufi has to go through [24], [25]. Kiai As'ad means sabar (patience) by enduring the test. According to Kiai As'ad, one of the keys to Wali Songo's success is because they have a patient personality. Therefore, a santri must have a strong personality, stand the test, and be determined. Especially if the santri are preaching during society [9], [21]. Sabar is being graceful when a bitter experience is overtaken, displaying a rich attitude by hiding poverty in life, and still behaving well [24].

\subsubsection{Living Simply and Modestly (qonaah, ridha, and ikhlas)}

Quality of life that is recommended among pesantren, living simply and modestly describing the acceptance of life as it is. Among them: qonaah (accepting the reality), ridha (peace of mind accepting the provisions of Allah), and ikhlas (the act of cleansing and purifying the heart from other than Allah) [17], [21], [23]. Ridha is the peace of heart to accept the provisions of God. He will not complain about the bitter fate that befell him. He will be willing to accept reality, gifts, and provisions from God (nrima ing pandum). Ridha usually, preceded by the nature of qona'ah. Qona'ah is an attitude of acceptance and acceptance of the existing reality. People who are qona'ah will stay away from delusion and consider something in front of them. He will feel rich even if he is starving physically. He always gives help even though his wealth is small. He is rich in heart, not greedy. The soul feels free from suffering and delusion that will never happen [24]. Ikhlas is an act of cleansing and purifying the heart of something other than Allah. Signs of ikhlas people are: there is no difference when receiving praise and scolding, not looking at the deeds of his deeds, and does not demand merit [24].

\subsubsection{Tawadhu' and wawas diri (guard appearance, speech and mind)}

According to Kiai As'ad, one of the keys to success is having a tawadhu' personality. Tawadhu' is a humble attitude which is the implication of ikhlas attitude. People who are tawadhu', according to Abu Yazid, are people who do not consider themselves to have a position and do not view others as bad. According to Ibn Atha, tawadhu' is a person who accepts the truth from others [24]. What is related to tawadhu' is wawas diri (selfawareness), which is to look up, keep your words, keep your heart and attitude to others. Maintain appearance, for example, simple clothes but always clean, neat, and pure. He was calm, rarely spoke, always smiling and sweet, he said. Keeping his words, for example: do not say dirty, have smooth words, sweet words must be able to distinguish rough and smooth language and be able to say it to whom [17]. 


\subsubsection{Communicative}

Kiai As'ad described, one of the keys to the success of the ulama (scholars) in ancient times was good communication. Ulama always establish ties of kinship and friendship. The ulama often hold meetings with the umara (government) who discuss development problems, education, and other religious and state matters. In some cities, there must be Jami Mosques, pendopo, prisons, and squares. [19], [26]. The communication is expected by Kiai As'ad, as well as the description of a good tree in Sura Ibrahim verses 24-25. In the context of building networking by Kiai As'ad the "interpretation" of the verse, namely: First, it has a firm root that has a strong-rooted mass base. Second, it has branches that soar up to the sky; it means having a wide network and great influence at the top level (for example party elites, community leaders, and top officials). And third, have fruit that can be picked every season; it means that the cadre can benefit the organization and the community [9], [18], [27].

The ideal quality of self that santri must develop can be categorized into two parts. First, shalahiyyah which shows scientific skills and skills; namely alim, wawas diri, and communicative. Second, Salih which shows the strength of moral integrity; namely honest and enterprising (as-shidq); compassion (rahmah); able to control themselves (wara, zuhud, and sabar); simple and modest (qonaah, ridha, and ikhlas); and tawadhu'. Shalahiyah and shalih must be integrated and harmonious. The quality of shalahiyyah must be accompanied by a righteous attitude to achieve happiness in the world and the hereafter. The ideal self also reflects harmony (at-tawazun) between lahiriyah and batiniyah. For example, alim must be a harmony between knowledge, practice, and seek the pleasure of Allah. Similarly, in showing affection, not only behavior that is visible but also that is not visible [28], [29].

Self-concept and ideal self among pesantren which are oriented towards self-quality, the benefit of the people, and expect God's pleasure is important to be improved in welcoming the society 5.0. because the key to the realization of society 5.0. programs in Japan is the combination of cyberspace and the real world (physical space) to produce quality data, and from there create new values and solutions to overcome challenges for human prosperity [1], [2], [30], [31]. Characteristics of society 5.0 or a super-smart society is a society that can provide products and services to others appropriately and correctly; and the person can receive a good quality of service so that they feel comfortable and full of enthusiasm regardless of their background [32].

To welcome the public, 5.0 humanist counseling groups, for example, Rogers, offer an ideal self so that the fully-functioning person. The fully functional concept of the human self is open to experience, existential life, belief in one's own organism, feeling free, and creative [33]. While the pesantren offer the ideal concept of santri as a generation of khaira ummah with the character of "Pelopor" (leaders in the way of Allah and leaders together with the people to build civilization). The ideal character of the self-khaira ummah is to harmonize the quality of shalahiyyah skills with the integrity of salih [21], [34].

Self-concept of santri as leader of khaira ummah; namely as an embodiment as a servant of God (worship) as well as the caliph of God (building civilization and making prosperity). Or leaders who have the character of "Pelopor" namely individuals who are able to become leaders in the way of Allah (da'wah) and leaders who fight for the people for prosperity and happiness in the afterlife is very interesting to be developed in career development studies in the era of society 5.0. A career is a manifestation of a person's life and meaningful life. This meaningfulness is because careers include life roles, life-settings, and life events. Career choice and development - according to self-concept theory — is basically the process of developing and applying one's self-concept [35]. This self-concept is the result of a dynamic 
interaction of the quality of one's personality and competence with others and the environment [36]

A person's self-concept varies greatly, depending on the person's culture. Markus and Kitayama differentiate one's self-concept into two. First, the independent self is an understanding of the self that is rigid, whole, and separate from the social context; this happens in Western culture. Second, interdependent self, namely the understanding of self as a self that is flexible, variable, and related to the social context; this occurs in Eastern cultures [37]. From the perspective of interdependent self-theory, a person's career is more meaningful if he is considered as part of a social relationship in which the person's behavior is assessed and depends on the person's understanding of the thoughts, feelings, and actions of others in a relationship [7], [38], [39] Research from New Zealand on the Maori Tribe shows that their interdependent and religious self-concept will have an impact on collectivity in the workplace, choose a workplace that respects the development of the Maori, and does not support the commercialization of Maori assets [40].

In the context of this research, a santri will be considered successful in his career, if other people also enjoy that person's career. Success in a career is not solely due to the quality and ability of that person, but also depends on the assessment of others; it is more concerned with collective cooperation rather than individuality. There is a balance between personal and social qualities where he is. In fact, in the view of santri, what was done in his career must also get the pleasure of God. Because of a career for happiness and prosperity in the world and the hereafter.

\section{Conclusions}

The era of society which is oriented towards human values in the use of technology 4.0 to solve social problems and economic growth, is very relevant to study with a psychological approach. One of the psychological studies is self; because to know humans must first understand themselves. One of the studies conducted by the writer is the development of the self-concept of female santri at Pondok Pesantren Salafiyah Syafi'iyah Sukorejo Situbondo. The development of santri's ideal self-concept is a generation of khaira ummah characterized by "Pelopor" namely leaders in the way of Allah and leaders with the people to build civilization. To implement the khaira ummah generation, santri develop a self-scheme that balances the quality of skills (shalahiyyah) with integrity (shalih). The quality of shalahiyyah which shows scientific skills and skills; namely pious, self-awareness, and communicative. Being the righteous integrity, which shows the strength of moral integrity; namely honest and enterprising (as-shidq); compassion (rahmah); able to control themselves (wara, zuhud, and sabar); simple and modest (qonaah, ridha, and ikhlas); and tawadhu'.

In the theory of self-concept in career development argues, choice and self-development is a process of developing and applying one's self-concept. The self-concept is the result of complex interactions among several factors, including physical and mental growth, personal experience, a person's characteristics, and environmental influences. Thus, the self-concept of students who are oriented to the values of worship and build civilization will also influence the development of students' careers. For example, in developing the economy of the people, according to one of their kiai's will. This character education needs to be developed in other educational institutions. 


\section{References}

[1] M. Fukuyama, "Society 5.0: Aiming for a New Human-centered Society," Japan SPOTLIGHT, vol. 27, no. Society 5.0, pp. 47-50, 2018.

[2] M. E. Gladden, "Who Will Be the Members of Society 5.0? Towards an Anthropology of Technologically Posthumanized Future Societies," Soc. Sci., vol. 8, no. 148, pp. 1-39, 2019.

[3] Santrock. J.W, Remaja. Jakarta: Erlangga, 2007.

[4] S. Arifin and Wisri, "Politik Kebangsaan Kiai Pesantren (Studi Kepribadian dan Perilaku Politik K.H.R. Ach. Fawaid As'ad Situbondo)," in 3rd Annual Conference For Muslim Scholars (AnCoMS), 2019, pp. 343-353.

[5] M. B. Brewer and W. Gardner, "Who is this 'we'? Levels of collective identity and selfregulations," J. Pers. Soc. Psychol., vol. 71, pp. 89-93, 1996.

[6] S. Arifin and H. Munfaridah, "Pengembangan Desain Konseling Berbasis Pesantren dengan Pendekatan Service-Learning,” J. Bimbing. dan Konseling Islam, vol. 08, no. 02, pp. 110-132, 2018.

[7] Shelley E. Taylor, L. A. Peplau, and D. O. Sears, Social Psychology. New Jersey: Pearson, 2003.

[8] K. S. Bordens and I. A. Horowitz, Social Psychology. Indiana: Freeload Press, 2008.

[9] S. A. Hasan, Kharima Kiai As'ad di Mata Umat. Yogyakarta: LKIS, 2003.

[10] M. A. Hogg and D. Abrams, Social identifications: A social psychology of intergroup relations and group processes. London: Routledge, 2006.

[11] Maurice, Service Learning Handbook. North Carolina: Guilford County Schools, 2010.

[12] Goldzweig, "Improving seat belt use among teen drivers: Findings from a service-learning approach," Accid. Anal. Prev., vol. 59, pp. 71-75, 2013.

[13] Al. Pervin and J. Oliver, Handbook of Personality: Theory and Research 2nd ed. New York,: Guilford Press, 1999.

[14] G. Caprara and D. Cervone, Personality: Determinants, Dynamics and Potentials. Cambridge: Cambridge University Press, 2000.

[15] B. Wong, Y. T. Chiu, and B. Wong, "Exploring the Concept of 'Ideal' University Student," Stud. High. Educ., vol. 0, no. 0, pp. 1-12, 2019.

[16] A. A. Ibrahimy and S. Arifin, Kiai Fawaid As'ad: Kepribadian, Pemikiran, dan Perilaku Politik. Situbondo: Tanwirul Afkar, 2018.

[17] A. A. Ibrahimy and S. Arifin, Risalah Hati: Trilogi Biografi Nyai Zainiyah As'ad. Situbondo: Tanwirul Afkar, 2019.

[18] S. Arifin, Sang Pelopor: Kisah Tiga Kiai dalam Mengelola Bekas Bajingan. Surabaya: Pena Salsabila, 2014.

[19] S. Arifin, Wejangan Kiai As'ad dan Kiai Fawaid. Surabaya: Pena Salsabila, 2014.

[20] S. Arifin, "Pesantren -Based Counseling in Changing The Behaviour of The Community of Former Bajingan Being Personal Characterless 'Pelopor,'” Umr. - Int. J. Islam. Civilizational Stud., vol. 07, no. 03, pp. 59-75, 2020.

[21] S. Arifin, At-Tawazun: Psikologi dan Konseling Berbasis Pesantren untuk Membentuk Karakter Khaira Ummah. Malang: Literasi Nusantara, 2020.

[22] A. Samsul and A. F. Risma, "The Model of Development Therapeutic Speech in the Digital Era: A Study of "Interpretation of Al- Mishbah ' for Cyber-Counseling Services," in Proceedings of the 19th Annual International Conference on Islamic Studies, AICIS 2019, 1-4 October 2019, Jakarta, Indonesia, 2020.

[23] S. Arifin, "A Portrait of the Sakinah Family in Manuscript Texts by Women Scholars from the Pesantren," J. Harkat, vol. 15, no. 1, pp. 51-59, 2019.

[24] Al-Qusyairi, Risalah Qusyairiyah. Jakarta: Pustaka Al-Amani, 1998.

[25] S. Arifin, "Menjadi Warga Negara Khaira Ummah Dengan Hidup Sehat Tanpa Korupsi,” J. Konseling Reli., vol. 9, no. 1, pp. 39-60, 2018.

[26] S. Arifin, "Komunikasi Kiai Pesantren: Pemberdayaan Komunitas Bajingan Perspektif Komunikasi Konseling," in 2nd Proceedings Annual Conference for Muslim Scholars, 2018, no. April, pp. 330-338. 
[27] S. Arifin and A. Zaini, "Dakwah Inklusif di Kalangan Bajingan : Membedah Komitmen Bekas Bajingan dalam Membangun Peradaban Perspektif Psikologi Sosial,” J. Dakwah, vol. XIX, no. 1, pp. 29-50, 2018.

[28] S. Arifin and A. Zaini, "Decision of Implementing Uzlah and Gerbat Techniques in Islamic Boarding School as Preparedness Response for Covid-19 Pandemic,” Unnes J. Public Heal., vol. 9, no. 2, 2020.

[29] S. Arifin and H. Munfaridah, "Local Wisdom Development of Pesantren Based Counseling Design with Approach Service-Learning," in International Conference On UniversityCommunity Enggagement October 8-10, 2018, 2018, vol. 3, no. 2, pp. 816-832.

[30] N. Suzuki, "Contributing to SDGs and Society 5.0 through Open Collaborative Creation and Innovative Research," Hitachi Rev., vol. 68, no. 4, pp. 22-26, 2020.

[31] C. M. Ferreira and S. Serpa, "Society 5.0 and Social Development," Preprint, no. November, pp. 1-6, 2018.

[32] Y. Harayama, "Society 5.0: Aiming for a New Human-centered Society," Japan SPOTLIGHT, pp. 8-13, 2018.

[33] Gerald Corey, Theory and Practice of Counseling and Psychotheraphy. Belmont: Thomson Higher Education, 2009.

[34] A. Zaini and S. Arifin, "Environmentally Sound Empowerment Da'wah For Conflict Areas of Baluran Forest Situbondo," in International Conference On University-Community Enggagement October 8-10, 2018, 2018, pp. 40-51.

[35] D. E. Super, "A Lfe-Span, Life-Space Approach to Career Development," in Career Choice and Development: Applying Contemporary Theories to Practice, D. Brown and L. Brooks, Eds. San Francisco: Jossey-Bass, 1990.

[36] L. S. Alvin and R. V. E. .A. Athanasou, International Handbook of Career Guidance. Springe, 2008 .

[37] H. Markus and S. Kitayama, "Culture and The Self: Implication for Cognitif, Emotion, and Motivation,” Psychol. Rev., vol. 98, pp. 224-253, 1991.

[38] S. Arifin and A. Zaini, "Transformative Da'wah Through Counseling for the Career Development of Coffee Farmer Groups in the Tourism Village Banyuwangi," J. Konseling Reli., vol. 10, no. 2, pp. 215-231, 2019.

[39] S. Arifin, "The Dynamics of Change in Relation Kiai Santri on 'Ngaji Online' in The Covid19 Pandemic,” J. Kependud. Indones., vol. 1, pp. 75-80, 2020.

[40] C. A. Houkamau and C. G. Sibley, "The Role of Culture and Identity for Economic Values: a Quantitative Study of Māori Attitudes,” J. R. Soc. New Zeal., vol. 49, no. 51, pp. 118-136, 2019. 